\title{
Operettas Staged by the Slovak National Theatre During the Years $1920-1938^{1}$
}

\author{
Michal Ščepán \\ Muzikološki inštitut Slovaške akademije znanosti \\ Institute of Musicology of the Slovak Academy of Sciences
}

In 2020, Slovakia commemorates the 10oth anniversary of its most important cultural establishment, the Slovak National Theatre. In the history of this institution, the first two decades were extremely complicated, and operettas played an important role on its stage.

With the Martin Declaration signed on 30 October 1918, the Slovaks officially declared their independence from Hungary and became part of a new country, Czechoslovakia. The new democratic conditions brought about significant progress in all fields, not only in the political and social spheres, but also in culture and education. In the $19^{\text {th }}$ century, the Slovak national awakening movement considered the latter two fields to be the foundations of national awareness. However, in the new state, both needed a proper centre for their development. Although the capital of the Slovaks in the Austro-Hungarian Empire was, at least implicitly, Turčiansky Svätý Martin, several cities in different parts of the country were taken into account when deciding on the capital within the new federal republic. In the end, the choice fell upon Bratislava.

One of the priorities of the Czechoslovak government was to acquire the territory of the city of Pozsony/Pressburg. The name Bratislava began

1 This article is the result of the implementation of the Personality and Work in the History of Musical Culture of the $18^{\text {th }}-20^{\text {th }}$ Centuries in Slovakia (No. 2/0116/20) project supported by the Scientific Grant Agency of the Ministry of Education, Science, Research and Sport of the Slovak Republic and the Slovak Academy of Sciences, Bratislava, Institute of Musicology of the SAS, 2020-2023. 
to be used for this in February 1919 when Vavro Šrobár, authorised to govern Slovakia, moved there. Bratislava officially became part of Czechoslovakia after the Treaty of Versailles on 28 June 1919. Besides its favourable location, one of the main reasons for choosing it as the capital was that there were enough buildings where the newly emerging institutions could move in. Talks about establishing a representative national theatre began already in May 1918, at the celebrations of the $50^{\text {th }}$ jubilee of laying the foundation stone of the National Theatre in Prague, in which a Slovak delegation, headed by the poet Pavol Országh Hviezdoslav, also participated. The Slovak National Theatre was primarily established due to the will of Slovak politicians rather than as a manifestation of some inner artistic need.

Although Bratislava was the capital of Slovakia, the proportion of Slovaks in the city's population was minimal. From the times of the Austro-Hungarian Empire, the population had been mainly Hungarian and German, and they had never imagined their city would once become part of Czechoslovakia. ${ }^{2}$ Slovaks were gradually arriving in Bratislava for work from other parts of the country, with the size of the population of the new state also increased by the arrival of Czechs. Therefore, the main political aim was to eliminate the German and Hungarian languages and replace them with Slovak and its culture. This, however, posed a major problem, since the Slovak National Theatre was neither Slovak nor national in its beginnings. Its operations were not managed by the state, but by a private company (a joint venture) called Družstvo Slovenského národného divadla [Cooperative of the Slovak National Theatre], established in 1919 and granted a concession by the Ministry of Education and National Enlightenment in Prague. ${ }^{3}$

Slovak amateur theatre, no matter how developed and branched out it was territorially, could not become the basis of a professional theatre. Therefore, the Cooperative decided to engage and commission Východočeská divadelni společnost [the South Czech Theatre Company] from Pardubice, which was headed by director Bedřich Jeřábek and consisted of three ensembles: drama, opera, and operetta. ${ }^{4}$ In the Municipal Theatre in Bratislava, this company was to alternate with Hungarian and German thea-

2 Zuzana Francová, "Obyvatelia - etnická, sociálna a konfesijná skladba," Bratislava: (Ročenka Mestského múzea), no. 10 (1998): 17-38.

3 František Bokes, "Družstvo Slovenského národného divadla," Slovenské divadlo 56, no. 2 (2008): 236-58.

4 Ladislav Lajcha, Dokumenty SND 1 (1920-1938). Zápas o zmysel a podobu SND, vol. 1 (Bratislava: Divadelný ústav, 2000), 7-25. 
tre companies, that served the needs of the original population, in a 1:1:1 ratio. During the 1920 s and 1930s, the theatre companies of Károly Polgár, Dezső Földes, Sándor Iván, Jozef Jarno, Paul Blasel or Rudolf Beer gradually operated in the city. ${ }^{5}$

Jeřábek's theatre company arrived in Bratislava with a complete repertoire, naturally in the Czech language, and this was one of the main objections of the representatives of Slovak national life, ignoring the fact that there were few Slovak original works and translations. Another essential objection was the operetta, which was seen as an unwanted element in the programme of the Slovak National Theatre. ${ }^{6}$ In the opening season, Jeřábek premiered 20 operettas in total, which is not a negligible number considering the four months the theatre had been in existence. ${ }^{7}$ Besides the works of Czech authors, such as Maharadžov miláčik [The Maharaja's Sweetheart] by E. Starý, which was the first ever operetta staged there, or Pol'ská krv [Polish Blood] by O. Nedbal, the programme of the Slovak National Theatre included Offenbach's Orpheus in the Underworld, Daphnis and Chloe, Kálmán's Csárdás Princes, Autumn manoeuvre, Strauss's Thousand and One Nights, and L. Fall's Rose of Stamboul. Jeřábek's aim was to attract a wider audience, for whom operettas suited because of their character. After all, musical theatre had a long tradition in Bratislava. ${ }^{8}$ Therefore, and also because of the smaller language barriers, even the German and Hungarian inhabitants of the city began to gradually attend these performances. Voices against operettas became stronger, though. A prominent music critic of the day, Ivan Ballo, spoke up in the press against staging operettas:

The Cooperative of the Slovak National Theatre is planning to stage an operetta in our theatre again. The writer is of the quite correct opinion that staging operettas as part of the programmes of the Slovak National Theatre means an artistic degradation and it will not

5 Milena Cesnaková-Michalcová, Premeny divadla: inonárodné divadlá na Slovensku do roku 1918 (Bratislava: Veda, 1981), 111-2.

6 Zdenka Bokesová, "O cestách vývoja operety v Bratislave," in Pamätnica Slovenského národného divadla, ed. Ján Ferenčík (Bratislava: Slovenské vydavatel'stvo krásnej literatúry, 1960), 238.

$7 \quad$ All the information about the premieres and the repeats comes from the following publication: Elena Blahová-Martišová and Ján Jaborník, Súpis repertoáru Slovenského národného divadla 1920-2010 (Bratislava: Slovenské národné divadlo, 2010).

8 Jana Lengová, "Hudba v období romantizmu a národno-emancipačných snáh (18301918): Hudobné divadlo," in Dejiny slovenskej hudby: od najstarších čias po súčasnost', ed. Oskár Elschek (Bratislava: ASCO Art \& Science, 1996), 206-7. 
do any good to the theatre or its attendance. The gentlemen in the cooperative have their own opinion. They figured one could prosper only with operettas. We admit that, from a financial aspect, the theatre is a business. But, if a business is not doing well, more work is to be done. Therefore, more knowledge in the management, more energy, and more authority is needed, not operettas.

Partly due to such invectives, operettas began to slowly disappear from the repertoire. In the first season, there were six of these, including works of lower quality, such as K. Moor's Mr. Professor in Hell or F. Albini's Barefoot Dancer. In the second season, which was the last one headed by Jerábek, no operettas were staged. Despite the subvention from Prague and the contributions by the city and the county, the Slovak National Theatre under Jeřábek did not manage to generate enough funds in its first three years, unlike the theatres in the Czech Republic. Although Slovaks already constituted over half of the population of the city in the 1920s, because of their jobs they had practically no time for attending the theatre, and were not even interested in it. Even if they were interested, going to the theatre remained a distant dream for many, which few could afford. Moreover, most left the city at the weekends and travelled home to their families.

The solution was to appoint a new director, which the Cooperative did by inviting Oskar Nedbal, a prominent Czech composer, conductor and entrepreneur. ${ }^{10}$ When he took up the post in 1923 , he undertook to fulfil one main task: to Slovakise the theatre to the largest possible extent, while maintaining a multi-ethnic Bratislava audience by introducing ballets to replace the unsuitable operettas. However, the latter did not disappear from the repertoire completely, but, contrary to his predecessor, Nedbal selected only high-quality, tried and tested works. An operetta composer himself, he did his best to keep this genre on the stage of the Slovak National Theatre. From his 1923 appointment onward, he focused on staging classical operettas which were artistically fully effective and followed the concept of operas, and which, consequently, required opera singers and a large symphonic orchestra. Among the already popular work that he staged were Strauss's Die Fledermaus and Gypsy Baron, F.R. Hervé's Mamzelle Nitouche, Offenbach's Orpheus in the Underworld, and Schubert and H. Berté's House of the Three Girls. Nedbal's own works, including Polish Blood and The Vineyard Bride, and two fashionable revue operettas, Z. Folprecht's

9 Ivan Ballo, "O operete," Slovenský denník 5, no. 172 (1922): 5.

10 Lajcha, Dokumenty SND 1 (1920-1938), 40-99. 
From Pressburg to Bratislava and J. Odcházel's From Bratislava to Shang$h a i$, also featured in the repertoire.

The shows were always staged with high artistic standards, which followed from Nedbal's circumspection in choosing the conductors and singers. In choreography and direction, the ballet master Achille Viscusi also participated in staging operettas. ${ }^{\text {II }}$ Despite all these strengths, however, no more than three operetta premieres, and a maximum of 15 repeats, took place a year under Nedbal's directorship till 1930 (with a short break in 19281929). The situation changed in the last year of Nedbal's activities, when a second stage, a so-called Folk Theatre was opened, which was to stage not only drama but operettas, too. Besides two premieres in the main building of the theatre, another three operettas were staged in the Folk Theatre, and this was the highest number under Nedbal's directorship of the Slovak National Theatre. Throughout his time in the theatre, Nedbal struggled with financial difficulties and did not manage to fully achieve the Slovakisation of the theatre, either. For this reason, he was constantly under attack. Although he did not do anything wrong as a manager and did not seek any wrongful personal gain (as confirmed by a financial audit), he could not put up with the pressure and committed suicide on Christmas Eve of 1930.

He was succeeded by an entrepreneur, Antonín Drašar, who took over the complete management of the Slovak National Theatre based on a concession granted in 1931. ${ }^{12}$ Over time, the annual programmes in the municipal theatre building settled definitively at a 10:1:1 ratio in favour of the Slovaks against the German and Hungarian minorities. In terms of the number of premieres and repeats, the time of Drašar's activities was the golden age of the operetta in the interwar period. Contrary to Nedbal, Drašar had a strong preference for operettas, which could also be seen in his previous activities in Národní divadlo moravskoslezské [the National Moravian-Silesian Theatre] in Ostrava, Divadlo sdružených měst východočeských [the Theatre of Associated East Czech Cities] in Kladno, and České divadlo [the Czech Theatre] in Olomouc. Drašar's inclination to the operetta was aptly characterised by a Czech singer and actor, Oldřich Nový, who had worked under him in Ostrava: "Drašar was known all over the empire for being obsessed with operetta."

11 Elena Martišová-Blahová, Slovenské národné divadlo 1920-1995 (fakty - osobnosti udalosti) (Bratislava: Národné divadelné centrum, 1996), 44.

12 Lajcha, Dokumenty SND 1 (1920-1938), 102-58.

13 Ladislav Tunys, Jen pro ten dnešní den. V hlavní roli Oldřich Nový (Praha: Ametyst, 2000), 38-9. 
Drašar continued this trend even in his activities in Slovakia, especially by engaging the operetta ensemble he had brought over from Olomouc, which was to replace Nedbal's ballet ensemble. However, the Folk Theatre did not bring the desired profit and it was closed in the spring of 1931. All the operetta shows were then transferred back to the main theatre building. From his appointment onward, Drašar attracted a wave of criticism not only for his preference for operetta over drama or opera, for securing the favourable spots for operettas during prime time on Saturdays and Sundays, and for costly sets for the operetta shows, but also for his preference for Berlin revue operettas (R. Benatzky, J. Gilbert, R. Stolz, J. Beneš) and adding Hungarian operettas to the repertoire (N. Brodszky, P. Abraham), for which he received generous commissions and royalties. After a year, such criticisms were also accompanied by resentment over the fact that he had become the art advisor of the Modern Operetta in the Variété in Prague. Moreover, objections about the unsuitability of operettas for the stage of the Slovak National Theatre were still ongoing. In one of the many discussions aimed against Drašar and operetta, the following was said:

Director Drašar introduced operettas into the Slovak National Theatre, operettas which have no worth artistically, which are kitschy and, on top of that, Hungarian. He was criticised for this at the first meeting, and has been criticised publicly in magazines and dailies, pointing out that operettas, especially in their current form, do not belong to the representative national stage, as they suppress true art to a subordinate level, dull refined taste for fine arts in the audience, etc. Previously, there were no operettas, except for some classical ones. High art was cultivated, the theatre stood on a certain height from an artistic aspect, and this is proven also by the fact that prominent artists emerged in the Slovak National Theatre who then proceeded to other major stages, e.g. to Brno and Prague. Operettas are played elsewhere, one might say, but not in a national theatre, not on national stages. That is not the case either in Prague, or in Brno; actually, nowhere else, I should say. ${ }^{\mathrm{I}}$

Drašar's plan with operettas was well considered and, as it soon turned out, his primary interest was not education or the establishment of a good ensemble with the prerequisites for continuous development, nor staging operettas in the Slovak National Theatre to gain funds for running it.

14 Terézia Ursínyová, Cesty operety (Bratislava: Opus, 1982), 48-9. 
Instead, he was interested in theatre entrepreneurship. This could be seen especially after his appointment as art advisor of the Modern Operetta in Prague, when the interactions between these two institutions became livelier, to the extent that they exchanged soloists and choir members, rehearsed the same repertoire, and shared their collections, especially those of the Slovak National Theatre. This entrepreneurial character of Drašar was noticed by the above-mentioned Ivan Ballo, who, although praising Drašar's abilities and entrepreneurial skills, noted that he lacked any artistic qualifications whatsoever. Just like in the previous period under Jeřábek, even now he addressed the issue of the operetta itself very sharply, saying that it demoralised the audience and killed even the last vestiges of its taste and sense for true and valuable art. ${ }^{\text {is }}$

However, Drašar was a very different director from Oskar Nedbal - he was a hard-headed businessman and an adamant pragmatist, who did not lose perspective and withstood this enormous pressure. Drašar's activities had their advantages, too. Besides dividing drama into separate Czech and Slovak ensembles, he could implement, mainly thanks to the profit gained from staging operettas, an experimental dramaturgy, including contemporary works that were financially risky and often turned out to be financially unviable because of their low attendance. This was admitted by another prominent critic and organiser of musical events, Gustáv Koričánsky, too:

After all, we must count on that damned capitalist money to finance contemporary opera and, since operettas are relatively lucrative according to Drašar's reliable figures, nothing else remains but to make use of them financially in favour of the opera. It does not sound nice, I know! However, the realm of the operetta is not that of the opera, so I do not worry about the operetta at all. I want to be fair even to the operettas though. It is secondary, maybe even parasitic art, but it does not always have to be the worst. Classical, or partly even modern, operettas, have inventive melodies envied by many symphonists. At the same time, operettas, a type of a convenient pseudo-art of townspeople, may have quite an entertaining, light esprit. ${ }^{16}$

For Drašar's era, it was typical that the members of the ensemble, the dancers, musicians of the orchestra, and conductors, had to perform in all

\section{Ibid., 50.}

16 Ibid., 47. 
genres. The same applied for the actors of the drama section who had to perform in operettas, too. For the latter, however, Drašar was systematically building a soloistic ensemble. He selected actors from other Czech and Hungarian theatres and, mainly, invited young talented singers from the Academy of Music and Drama in Bratislava. Under Drašar's management, the following prominent Slovak singers were admitted to the Slovak National Theatre: Margita Čésanyiová, Štefan Hoza, Mária Kišonová-Hubová, František Krištof Veselý, and Štefan Munk. Despite their ambition to perform opera, these young graduates sang mainly operettas.

Tenorist Štefan Hoza, who had joined the theatre in 1932, recalled the situation and the environment in which the young singers found themselves upon joining the Slovak National Theatre, and gave some information also about their engagement in operettas that followed from the terms and conditions of their employment contract:

Theatre attendance called for premiere after premiere. If a classical operetta was repeated 10 times, it was a success. Each member had to compulsorily perform in all the shows, be it drama, operetta, opera, ballet, pantomime, revue, narrative plays, outdoor shows, matinées, night shows, or any other event throughout the Czechoslovak Republic organised by the Slovak National Theatre. The contract also stated that: 'The member is engaged from 15 August 19 ... for a period of one year. Each member is entitled to a 14-day holiday of paid leave. If the holiday lasts for six weeks or two months, the member of the Slovak National Theatre receives $75 \%$ of his salary for the entire period of the holiday. The holiday is determined by the director. The working hours consist of rehearsals and shows. The duration of the rehearsals - on days when the member performs - must not exceed five hours and must not last longer than until 4 pm. On days when the member has no show, he shall rehearse for eight hours and even in the evening. If rehearsals are necessary due to a sudden change in the repertoire or for some other reason, the member shall rehearse even on Sundays. The management reserves the right to change the casting. A member who rejects the assigned role or refuses to perform in any show, may be immediately dismissed and loses all his right to a salary. In each case, the management has the right to demand a penalty amounting to the member's annual salary. ${ }^{n}$ 
However, despite these tough conditions, and despite the fact that the young singers could not sing in operas and follow their own ideas, performing in the operettas enabled them to progress significantly in terms of agility and acting. According to Janko Blaho, a renowned Slovak tenor active in theatre from 1927, the conditions outline above, along with Drašar's ability to recognise talent and perspective in young artists, led many of them to become professional actors and singers. ${ }^{18}$

The sentiments against Drašar culminated in a demonstration at the time of the premiere of Abraham's operetta Ball at the Savoy (29/04/1933). This event, which had an anti-Czech and anti-Hungarian character and in which mainly students participated, was so tumultuous that the show had to be discontinued, despite an intervention by the police. Alexander Moyzes, a young composer, and reviewer of cultural life, reported on this event and on the situation of the theatre in Bratislava in the art and literature magazine Elán as follows:

The Bratislava audience got a glimpse of the mysteries and beauties of the new art and wants the same as the audience has in Vienna and Prague. The late Oskar Nedbal allowed some delicacy, by Strauss or himself, only here and there, Kálmán also got a chance here and there, but it was always rendered very nobly. Drašar's new regime keeps throwing these delicacies in handfuls. It is understandable that, due to their inadequate and superficial education in theatrical matters, our audience throws itself into the embrace of a crippled muse with passion. What to say then when ten times fewer people come for the première of an opera than for the $20^{\text {th }}$ repeat of an operetta? Our nice youth wants entertainment, and they get it by the operetta shows of the Slovak National Theatre. How terrible that demonstration against Hungarian operettas was - and, at the same time, we do not see the same youth no longer enjoying operettas which are sometimes even more Hungarian than the one they booed. It is a tough nut how to solve the problems of the opera in the Slovak National Theatre, which is, as of now, the least sought-after element of our theatre and brightens only with very costly guests from abroad. The fault is on both sides: the theatre management as well as the audience. Drašar is an entrepreneur of the theatre for which he receives subvention from the state, the country, and the city of Bratislava. He should not have given such 
scope for the operetta and set up a special ensemble for it. However, if our audience wanted to have a theatre that fulfils its mission, it should have innovated the operetta shows and protested against this harmful element in our theatre in that way. ${ }^{19}$

This demonstration was one of the factors that prompted Drašar to look for ways to improve his relationship with the Slovak cultural public. Besides staging operettas in Slovak, with Lehár's Paganini (11/11/1933) being the first step in this direction, he focused mainly on staging the works of local authors. Ján Móry’s Zimný románik [Winter Story] is considered to be the first Slovak operetta staged in the Slovak National Theatre. However, its premiere on 6 February 1932 provoked a serious controversy, not because of the quality of the operetta itself but, rather, because of the origin of its author, which was a thorn in the flesh of nationalistically oriented critics. Although Ján Móry came from Slovakia, he kept his Hungarian nationality even after the dissolution of Austria-Hungary. He studied composition in Budapest and Berlin, and his works were strongly influenced by the character of the musical life of these cities. Móry's fourth operetta in three acts set a German libretto written by Erwin W. Olbricht and Kurt Wunger. Drašar staged it in Czech translation during his activities in the Olomouc theatre in České Budějovice, a seasonal centre at that time (22/01/1931). It was conducted by Jiří Viliam Schöffer, who was the conductor of its Bratislava staging, too. Since Hungarians viewed Móry as their compatriot living abroad, the reviews in the Hungarian press were more than positive:

The plot is not stereotypical, it is filled with nice experiences permeated with love and cheerfulness during winter sports. The music is full of softness, its melodies are dominated by strength and feeling, which is a unique feature of each composition of Móry's. The operetta also contains modern hits and a rumba, which brings it closer to the musical productions of bars and cafés. The audience, which filled the theatre and, because of the composer, included an impressive number of Hungarians too, welcomed the operetta warmly and affectionately greeted Móry, who had achieved significant success even in Germany. ${ }^{20}$ 7. 20. Storočia” [Ján Móry and the Bratislava Stagings of his Operettas in the First Half 
The Slovak press received Móry's operetta very differently. The Slovák daily criticised the operetta for its weak libretto with its non-dynamic and boring plot, but appreciated the beautiful melodies and the rich instrumentation of the music. ${ }^{21}$ The most critical review of the operetta was written by Alexander Moyzes in the Národný denník daily under the title What All Wants to Get Away With Under the Label of "Being Slovak"? At the very beginning of the article the author criticises labelling the work as Slovak, points out the translation of the libretto, and evaluates the operetta as a very poor work on the whole. He asks:

How dare Slovak composers hide everything that is distasteful and impotent under the pretext of being Slovak? And how did it make it to the stage of the Slovak National Theatre? $?^{22}$

This example also reveals that the problem of the national character of the artistic productions of the Slovak National Theatre did not get solved in the 1930s, either. Another musical-dramatic work by Móry staged by the Slovak National Theatre was his operetta La Valliére, setting again a German libretto, this time by Günther Bibo, and having been premiered in Berlin. In Bratislava, it was performed on 5 April 1935 in Slovak translation and, paradoxically, it figured in Drašar's application for subvention for the following season as a work of the world repertoire. ${ }^{23}$ On the whole, Móry's operettas made use of every detail very sensitively to depict the characters and differentiate them with the music, but, at the same time, he did not abandon the typological schemes of Viennese operetta. In his inventive and rich melodies, he followed the contemporary orientation towards European entertainment music (especially dance songs) and did not shy away from modern harmonic structures, while placing emphasis on monumental instrumentation. ${ }^{24}$

Drašar's era was also the time of the beginning of the career of the most famous Slovak composer of operettas, Gejza Dusík. Already during his studies at the grammar school, Dusík composed several popular dance songs. After four semesters of studying medicine, he left the university and decided to devote himself fully to music. He began studying composition at

of the 2oth Century], in Vybrané štúdie k hudobným dejinám Bratislavy, ed. Jana Lengová (Bratislava: Veda, 2006), 121.

21 Ibid., 121-2.

22 Ibid., 122.

23 Ibid., 125 .

24 Ibid., 133-4. 
the New Viennese Conservatory (Neues Wiener Conservatorium). His first operetta, Tisíc metrov lásky [A Thousand Metres of Love] was premiered in the Slovak National Theatre in Bratislava even before his graduation. He composed it based on the theme of a comedy by Emanuel Brožík in collaboration with Juraj Haluzický. After the premiere of this three-act operetta (5 December 1935), the critics noted the entrance of a prominent figure on the scene of Slovak entertaining musical productions:

Gracious melodies, delightful to the ears of the audience, intertwine with the entire plot, and they will soon become popular. The lively jazz rhythms in various forms of modern dances came as a surprise. The instrumentation makes a skilful use of all the possibilities of timbre - up to dense, rich sound. ${ }^{25}$

The premiere of his second operetta, Ked' rozkvitne máj [When May Bursts into Blossom], took place on 14 May 1938. The praise that this threeact operetta received, whose libretto was written by Pavol Braxatoris, surpassed all expectations. One report noted that:

the whole work matched and, in certain aspects, even exceeded the standard of the regular foreign operettas, while a touch of softness and grace leaves a pleasant impression of this operetta. ${ }^{26}$

Unlike Móry, Dusík fully declared his Slovak nationality, and even his music had a Slovak (folk) character in terms of melody and rhythm, which was one of its positive features praised by the critics. In this operetta, Dusík drew on the style outlined in his first, and this style became characteristic of his work. Although he based his operettas on his own lyrical melodies, or on modern rhythms (fox, tango, waltz), for a long time he followed the formal scheme of Viennese operettas with a lyrical and a young comic pair, with a preference for closed pieces of a song character, and insertions of dance pieces often created from the central melodies. The prelude summarises the most striking melodies and rhythms. He used recitatives, melodrama and more elaborately composed musical pieces only in his later operettas. However, what is unrepeatable and omnipresent is the folk character of Dusík's melodies and his response to contemporary, modern rhythms. ${ }^{27}$

Ursínyová, Cesty operety, 68.

Ibid., 69.

Terézia Ursínyová, “Vyhostené (?) dieta múz,” Hudobný život 39, no. 5 (2007): 27. 
The negative attitudes toward Drašar slowly ceased, partly because the Modern Operetta in Prague closed down in 1935. With that, the profile of the operetta repertoire of the Slovak National Theatre began to change. The operations were simplified, there were fewer exchanges between Bratislava and Prague, the sets became less costly, and more scope was given in the operettas to opera singers, or even to young singers, who were cast mainly in operettas. In the Slovak National Theatre, the operetta returned to the classics and to pieces in which opera singers could shine. The repertoire included Nedbal's Polish Blood, Strauss's Gypsy Baron and Die Fledermaus, Lehár's operettas surprisingly ignored by the previous directors, Giuditta, Frasquita, The Tsarevich, The Merry Widow, The Count of Luxembourg, The Land of Smiles, Kálmán's Circus Princess, Countess Maritza, and Millöcker's Beggar Student. From among contemporary operettas, Frimml's RoseMary, Benešs $Z$ pekla štastie [Dead Lucky], Stratená varta [Godforsaken], $\mathrm{Na}$ tej lúke zelenej [On that Green Meadow] and U svätého Antoníčka [At Saint Anthony] were staged.

As the artistic standard was always high, not only J.V. Schöffer but also opera conductors like Zdeněk Folprecht, Josef Vincourek, Karel Nedbal, and Ladislav Holoubek were made to rehearse and conduct the operettas.

In total, 65 operettas were staged under Drašar's directorship until 1938, and their repeats were seldom in single digits. However, the events of 1938 put an abrupt end to his successful era. With the declaration of the First Slovak Republic, the Czechs became unwanted, Drašar was arrested and, after his release, had to leave Slovakia. The Slovak National Theatre became nationalised and a new chapter, in which operettas also played a role, opened in its history. This, however, is another story.

\section{Bibliography}

Ballo, Ivan. "O operete." Slovenský denník 5, no. 172 (1922): 5.

Bárdiová, Marianna. "Ján Móry a bratislavské inscenácie jeho operiet v prvej polovici 20. Storočia” [Ján Móry and the Bratislava Stagings of his Operettas in the First Half of the 2oth Century]. In Vybrané śtúdie k hudobným dejinám Bratislavy, edited by Jana Lengová, 117-41. Bratislava: Veda, 2006. Blaho, Janko. Zo skalického rínku. Bratislava: Tatran 1974.

Blahová-Martišová, Elena, and Ján Jaborník. Súpis repertoáru Slovenského národného divadla 1920-2010. Bratislava: Slovenské národné divadlo, 2010. 
Bokes, František. "Družstvo Slovenského národného divadla." Slovenské divadlo 56, no. 2 (2008): 236-58.

Bokesová, Zdenka. "O cestách vývoja operety v Bratislave." In Pamätnica Slovenského národného divadla, edited by Ján Ferenčík, 236-48. Bratislava: Slovenské vydavatel'stvo krásnej literatúry, 1960.

Cesnaková-Michalcová, Milena. Premeny divadla: inonárodné divadlá na Slovensku do roku 1918. Bratislava: Veda, 1981.

Francová, Zuzana. “Obyvatelia - etnická, sociálna a konfesijná skladba.” Bratislava: (Ročenka Mestského múzea), no. 10 (1998): 17-38.

Hoza, Štefan. "Naše operetné začiatky.” Hudobný život 3, no. 23 (1971): 3.

Lajcha, Ladislav. Dokumenty SND 1 (1920-1938). Zápas o zmysel a podobu SND. Vol. 1. Bratislava: Divadelný ústav, 2000.

Lengová, Jana. "Hudba v období romantizmu a národno-emancipačných snáh (1830-1918): Hudobné divadlo.” In Dejiny slovenskej hudby: od najstarších čias po súčasnost', edited by Oskár Elschek, 195-258. Bratislava: ASCO Art \& Science, 1996.

Martišová-Blahová, Elena. Slovenské národné divadlo 1920-1995 (fakty - osobnosti - udalosti). Bratislava: Národné divadelné centrum, 1996.

Moyzes, Alexander. “Opereta v prvej polovici sezóny 1933-34.” Elán 4, no. 5 (1933/4): 7 .

Tunys, Ladislav. Jen pro ten dnešní den. V hlavní roli Oldřich Nový. Praha: Ametyst, 2000.

Ursínyová, Terézia. Cesty operety. Bratislava: Opus, 1982.

Ursínyová, Terézia. “Vyhostené (?) diet’a múz." Hudobný život 39, no. 5 (2007): $24-7$. 